\title{
ジルコン酸鉛系圧電セラミックス基板を用いる $\mathrm{SH}$ 波デバイス
}

$\begin{array}{llllll}\text { 非会員 } & \text { 杉 } & \text { 崎 } & \text { 五 } & \text { 郎 } & \text { (東京理科大) } \\ \text { 正 員 } & \text { 竹 } & \text { 中 } & & \text { 正 } & \text { (東京理科大) } \\ \text { 正 員 坂 } & \text { 田 好一郎 } & \text { (東京理科大) } \\ \text { 正員 } & \text { 戸 } & \text { 田 } & \text { 耕 } & \text { 司 } & \text { (防衛 大) }\end{array}$

\section{Shear Horizontal Wave Device Using $\mathrm{PbZrO}_{3}$-Based Piezoelectric} Ceramic Substrate

Goro Sugizaki, Non-member, Tadashi Takenaka, Member, Koichiro Sakata, Member (Science University of Tokyo), Kohji Toda, Member (The National Defense Academy)

The piezoelectric constants and propagation characteristics of shear horizontal (SH) waves in a $\mathrm{PbZrO}_{3}$-based ceramic substrate are described. Numerical analysis for the phase velocity of $\mathrm{SH}$ waves is carried out under various electrical and mechanical boundary conditions. The results confirmed experimentally are given in the form of a function of the product of the frequency and the substrate thickness, which suggest that the zeroth-order symmetrical $\left(S_{0}\right)$ mode is promising for the device construction because of high electromechanical coupling and low dispersive property. The $S_{0}$ mode device is in a single mode operation in a considerably wide frequency range, which is suitable for constructing a stable oscillator. A delay line oscillator is composed of the $S_{0}$ mode device, an amplifier and an electrically controllable phase shifter, of which oscillation frequency varies with the applied voltage. The oscillator has fine frequency modulation characteristics over a wide frequency range from $\mathrm{DC}$ to $100 \mathrm{kHz}$. The device performance is useful for FM signal processing or voltage sensing.

キーワード : ジルコン酸鉛系圧電セラミックス, SH 波, SH 波デバイス, 遅延線発振器, 周波数変調

\section{1. まえがき}

反強誘電体であるジルコン酸鉛は, 数 $\mathrm{mol} \%$ の適当 なペロブスカイト形強誘電体で置換することによって 室温で強誘電性を示すことが知られている(1)。ジルコ ン酸鉛を主体とする強誘電体セラミックスは誘電率と 誘電損失が小さく, 自発分極の温度変化が比較的大き いことから，焦電材料としての研究と実用化が進めら れ，既に一部では実用の域に達している(2)。一方，弾 性波デバイス基板としての材料特性の評価に関する報 告はほとんどなく，波長に比べて薄い基板を伝わる板 波, すなわち，Lamb 波やShear Horizontal (SH) 波
の伝搬特性に関してはまだその検討がされていない。 弾性表面波（SAW）を問題にする場合には，波長 に比へてて分な厚さの基板が必要であるため ${ }^{(3)}, \mathrm{HF}$ 帯を含めて比較的低周波域でのデバイスの構成には不 向きとされ，実用上数十 $\mathrm{MHz}$ 以上の領域で使用され ている。板波には波長よりも薄い基板を伝搬するモー ドが複数個存在すると共に, それらのモードは SAW モードよりも電気機械結合係数が高い場合が多いとい

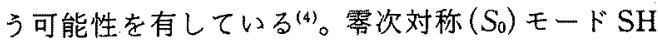
波は純弾性的であるときに，速度分散のないことが知

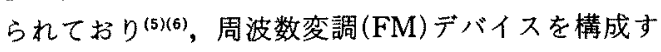
るうえで良好な位相特性を期待することができる。 
圧電セラミックスは結晶の対称性が高いために，単 結晶に比へて伝搬特性が単純であると予想される。分 極軸に垂直な面内にすだれ状トランスデューサ(IDT) を設けると，Lamb 波やSAW は励起されるが，SH 波は問題外となる。一方，分極軸に平行な面内でしか も分極軸に垂直な方向へはSH 波しか励起されない。 この上うな SH 波が利用できる横方向分極基板に関し て，SH 波を用いるデバイスを設計するうえで不可欠 な伝搬特性を明らかにすると共に実際的なデバイスを 構成し，実験的にFM 変調特性を検討することが本 研究の目的である。

\section{2. 試料の作成と材料定数}

SH 波デバイスの設計に必要な波動の伝搬特性を明 らかにするために，普通焼成法によってセラミック基 板を作成し, 弾性・圧電定数などの材料定数を測定し た。SH波デバイス用基板は，' $100 \mu \mathrm{m}$ 以下の厚みの 試料の作成が比較的容易に行えるようにテープキャス ティング法により準備した。出発原料は $\mathrm{PbO}, \mathrm{ZrO}_{2}$, $\mathrm{ZnO}, \mathrm{Nb}_{2} \mathrm{O}_{5}, \mathrm{TiO}_{2}$ で，純度はいずれも $99 \%$ 以上の ものである。科量した原料はアセトン，ジルコニアポ 一ルと共にボールミルで湿式混合した後, $800^{\circ} \mathrm{Cで} 1$ 時閒仮焼した。更に，ボールミルと遊星ミルにより粒 径が $1 \mu \mathrm{m}$ 以下になるまで微粉砕した後, 溶剤とバイ ンダを適量加えて十分混合し，脱泡を行うことによっ て，テープ用スシリーを作成した。スラリーをドクタ ーブレードを用いたテープキャスティング装置で厚さ 約 $100 \mu \mathrm{m}$ に成膜後, 適当枚数を積層熱圧着し, $\mathrm{MgO}$ るつほ中で $1,280^{\circ} \mathrm{Cで} 1$ 時間本焼成した。焼成後の冷 却は $100^{\circ} \mathrm{C} / \mathrm{h}$ 以下の温度こう配で行った。焼成後の セラミックスの密度比は $96 \%$ 以上であった。得られ た試料に導伝性銀塗料で形成した電極を用いて分極し た後, 所望の寸法にダイヤモンドカッタで切出し, 更 に研磨を施した。

誘電定数は, LCR ータ（YHP 4275）を用いて $10 \mathrm{kHz} お け る$ 值を測定した。圧電定数はIEEE 基 準(7)に準じて共振一反共振法により求めた。すなわ ち，圧電体のアドミタンス周波数特性加ら，共振周波 数 $f_{r}$ および反共振周波数 $f_{a}$ を測定し，電気機械結合 係数 $k$ 抢よび周波数定数 $N$ （試料を伝搬する音速の 1/2) を求め, 一連の計算手順( ${ }^{(8)} て ゙$ 圧電諸定数を求め た。測定対象とした振動モードは，円板の径方向広が

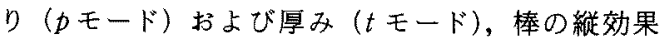
伸び (33モード)，方形板の長さ方向（31モード）扔 よび厚み滑り（15モード）振動である。0.92 $\mathrm{PbZrO}_{3}$ $0.032 \mathrm{~Pb}\left(\mathrm{Zn}_{1 / 3} \mathrm{Nb}_{2 / 3}\right) \mathrm{O}_{3}-0.048 \mathrm{PbTiO}_{3}(\mathrm{PZNT}(92 / 4.8)$
と略記了の $20^{\circ} \mathrm{C} て の$ 測定結果を以下にまとめている。

$$
\begin{aligned}
\left.l c^{E}\right]= & {\left[\begin{array}{cccccc}
14.9 & 5.82 & 5.13 & 0 & 0 & 0 \\
5.82 & 14.9 & 5.13 & 0 & 0 & 0 \\
5.13 & 5.13 & 14.2 & 0 & 0 & 0 \\
0 & 0 & 0 & 5.27 & 0 & 0 \\
0 & 0 & 0 & 0 & 5.27 & 0 \\
0 & 0 & 0 & 0 & 0 & 4.53
\end{array}\right] } \\
& \times 10^{10}\left(\mathrm{~N} / \mathrm{m}^{2}\right)
\end{aligned}
$$

$$
\begin{aligned}
& {[e]=\left[\begin{array}{cccccc}
0 & 0 & 0 & 0 & 3.35 & 0 \\
0 & 0 & 0 & 3.35 & 0 & 0 \\
-0.41 & -0.41 & 5.46 & 0 & 0 & 0
\end{array}\right]} \\
& \left(\mathrm{C} / \mathrm{m}^{2}\right) \\
& {\left[\varepsilon^{s} / \varepsilon_{0}\right]=\left[\begin{array}{ccc}
287 & 0 & 0 \\
0 & 287 & 0 \\
0 & 0 & 212
\end{array}\right]} \\
& \rho=7,612 \mathrm{~kg} / \mathrm{m}^{3} \\
& c^{E} \text { : 弾性定数, } e \text { : 压電定数, } \varepsilon^{s} / \varepsilon_{0} \text { : 比誘電 } \\
& \text { 率, } \rho \text { : 密度 }
\end{aligned}
$$

\section{SH 波の伝搬特性}

$\mathrm{SH}$ 波には複数個のモードが存在し，それらの位相 速度と電気機械結合係数 $k^{2}$ 法基板の厚さと波長の関 係に大きく依存することから，基板上での SH 波の伝 搬特性を明らかにすることはデバイス構成上不可欠で ある。伝搬特性の解析には，二つの自由境界面を有す

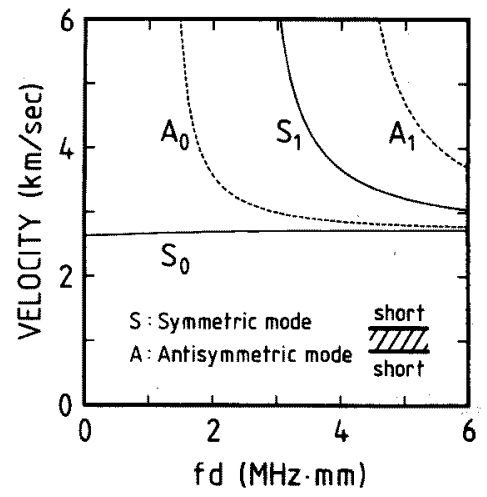

図 1 周波数 $f$ と基板の厚さ $d$ の積を变数 とする SH 波速度分散特性の数值計算結果

Fig. 1. Numerically calculated dispersive characteristics of $\mathrm{SH}$ waves as function of product of frequency $f$ and plate thickness $d$.

T. IEE Japan, Vol. 112-A, No. 9, '92 
る区電体の波動伝搬問題としてとらえ，Farnell らに よる方法を基にして数值計算を試みた(2) (11)。压電基 板の両面で電気的・機械的境界条件を满足する形で圧 電方程式と運動方程式から変位と電位を算出してい る。電気的境界条件では, 境界面が開放状態のときに 電束が連続で，短絡のときに電位が零である。機械的 境界条件ては圧電基板と空気との界面が機械的に拘束 のない自由境界面であるため垂直方向成分を含む応力 のテンソル成分は零である。

図 1 は SH 波の位相速度を周波数 $f$ と基板の厚さ $d$ の積 $f d$ の関数の形で表現した数值計算結果で，So モードは $f d$ 值が零から存在する唯一のモードである

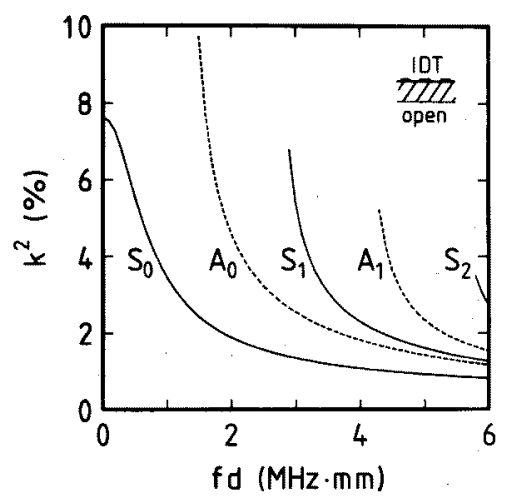

図 2 IDT/open状態でのIDTの $k^{2}$ の $f d$ 依存性の数值計算結果

Fig. 2. Numerically calculated $f d$ dependences of $k^{2}$ of IDT under condition of IDT/open.

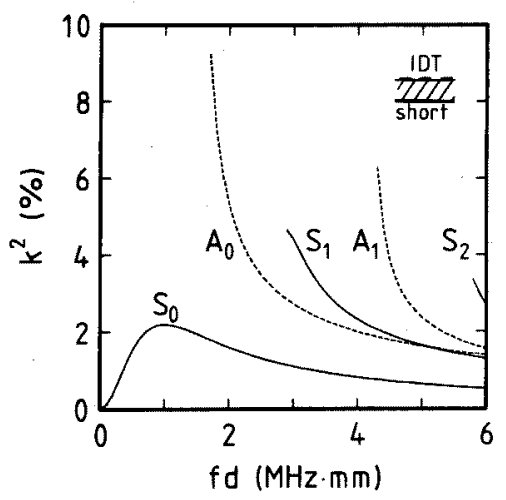

図 $3 \mathrm{IDT} /$ short 状態でのIDTの $k^{2} の f d$ 依存性の数值計算結果

Fig. 3. Numerically calculated $f d$ dependences of $k^{2}$ of IDT under condition of IDT/short.

電学論A，112 巻 9 号, 平成 4 年
と同時に純弾性関数状態にあるときには速度分散が存 在しない。ここては短絡条件下にあり, 圧電基板の二 つの自由面が電気的に短絡した場合の特性を示してい る。若干の速度分散を生じている。 $S_{0}$ モード以外の すべてのモードには臨界的にモードが出現する遮断周 波数が存在する。 $S_{0}$ モードだけの存在領域があり， この領域で動作するSH 波デバイスを設計することは 有利な特性につながるといえる。

図 2 と図 3 は二つの自由境界面の一方か゚IDT, 他 方の面が電気的に開放か短絡状態での IDT の電気機 械結合係数 $k^{2}$ を, $f d$ 值の関数の形で算出した結果を 示している。基板のIDT との対向面が電気的に開放

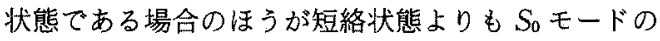
結合係数は高い。しかも開放状態では $1 \mathrm{MHz} \cdot \mathrm{mm}$ 以 下の $f d$ 值の領域で $3 \%$ 以上という大きい值を有する。 二つの図の比較から明らかなように，対称モードはい ずれも開放状態での $k^{2}$ 值が大きく，反対称モードは 反対の傾向を呈している。

\section{4. 遅延線発振器の構成}

前章での SH 波の伝搬特性の数值解析結果から， $S_{0}$ モード SH 波は低分散性で，3\%以上の高い結合係数 を有することが明らかになった。これらの特性を生か す形の具体的デバイスとして遅延線発振器を構成する

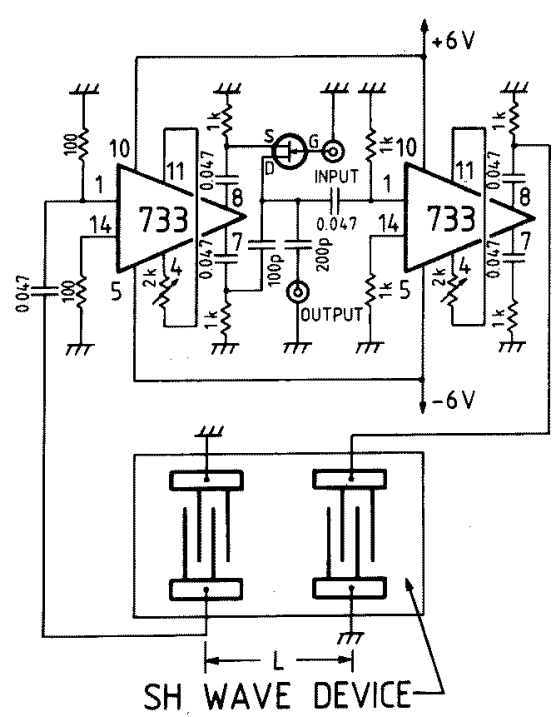

図 4SH 波遅延線発振器を用いる 電位七ンサの回路図

Fig. 4. Voltage sensing circuit using $\mathrm{SH}$ wave delay line oscillator. 
ことを試み，電圧印加に対応する周波数変調特性を評 価した。

図 4 はSH 波デバイスと增幅器と移相器の組合せに よって遅延線発振器を構成した実際の例を示してい る。可変抵抗素子として使用する J-FET (2 SK 117) とコンデンサ $(100 \mathrm{pF})$ が移相器の機能を果たしてい る。測定信号 (変調信号)をJ-FETのGate-Source 間に印加すると, Drain-Source 間抵抗 $R_{\mathrm{D}-\mathrm{s}}$ が電圧值 と共に変化し, 回路の位相遅延量が移動する。このフ イードバックループが発振を維持するためには以下の 振幅と位相条件を満足する必要がある。

$$
\begin{aligned}
& G(\mathrm{~dB})-I L(\mathrm{~dB}) \geqq 0 \\
& \phi_{A}(\mathrm{rad})+\phi_{E}(\mathrm{rad})=-2 n \pi
\end{aligned}
$$

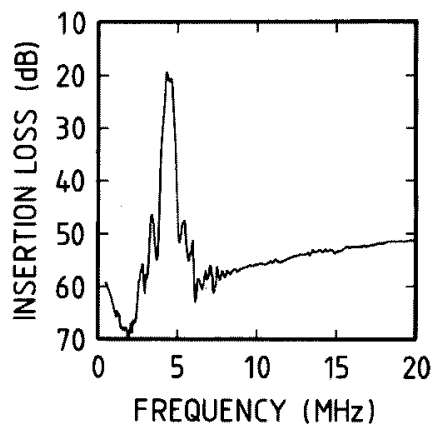

(a) $0.3 \sim 20 \mathrm{MHz}$
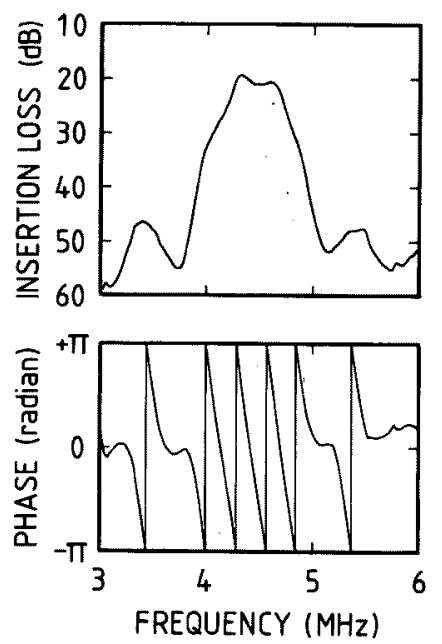

(b) $3 \sim 6 \mathrm{MHz}$

図 5 発振器に用いた $S_{0}$ モードSH 波遅延 素子の周波数特性

Fig. 5. Frequency characteristics of $S_{0}$ mode-SH wave delay line device for oscillator.
ここで, $I L:$ 素子の㨂入損失, $G:$ 回路の 利得, $\phi_{A}$ : 音響的な位相, $\phi_{E}:$ 電気的な位 相, $n:$ 発振次数

発振周波数を $f(\mathrm{~Hz}), \mathrm{SH}$ 波の位相速度を $v(\mathrm{~m} / \mathrm{s})$ ， 伝搬路長を $L(\mathrm{~m})$, 移相器の電圧に対する位相変化の 比例定数を $B(\mathrm{rad} / \mathrm{V})$, 移相器によらない位相漣延量 を $\phi_{0}(\mathrm{rad})$ とすると， $\phi_{A}(\mathrm{rad})$ および $\phi_{E}(\mathrm{rad})$ は次式 で与えられる。

$$
\begin{aligned}
& \phi_{A}=-2 \pi f L / v \cdots \\
& \phi_{E}=B V_{\mathrm{G}-\mathrm{s}}+\phi_{0}
\end{aligned}
$$

結果的には， $f$ は次式で表現できることになる。

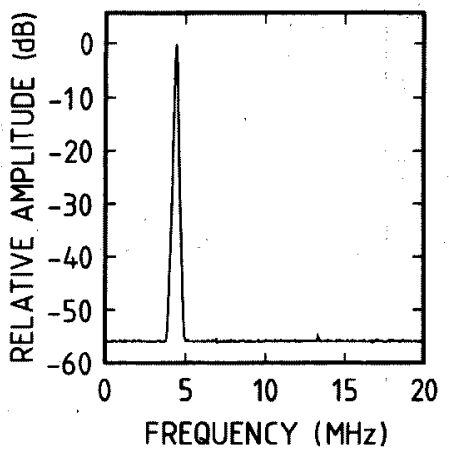

図 6 発振スペクトルの測定結果 Fig. 6. Measured oscillation spectrum.

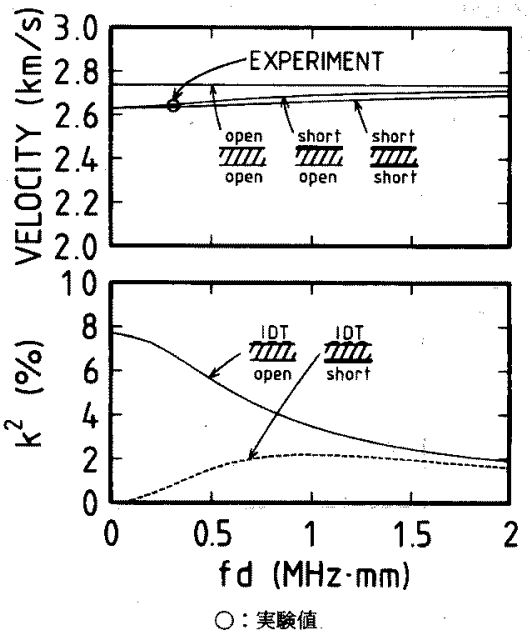

図 $7 S_{0}$ モード SH 波の位相速度と $k^{2}$ 值の $f d$ 依存性

Fig. 7. $f d$ dependences of phase velocity and $k^{2}$ for $S_{0}$ mode-SH wave. 


$$
\begin{aligned}
& f\left(V_{\mathrm{G}-\mathrm{s}}\right) \\
& \quad=B V_{\mathrm{G}-\mathrm{s}} /(2 \pi L)+\left(2 n \pi+\phi_{0}\right) v /(2 \pi L)
\end{aligned}
$$

すなわち，発振周波数はJ-FETに印加される Gate 電圧に依存し，しかも直線関係にある。

使用した SH 波趛延素子の基板寸法は $12 \times 18 \times$ $0.07 \mathrm{~mm}$ で, $14 \mathrm{p}$ サイズのICソケットに固定されて いる。索子基板の一方の面には, 電極周期長 $2 P$ が $600 \mu \mathrm{m}$, 電極指の数が 7 対の IDT が $9.6 \mathrm{~mm}$ の距離 を隔てて 2 個設けられている。SH 波遅延デバイスの 特性が図 5 に示されている。(a)図は $A_{0}$ 以上のモー ドが存在しない周波数領域であるために， $S_{0}$ モード だけの安定な発振特性を得るために有利である。(b)

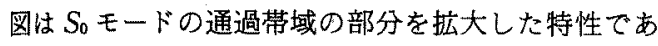
るが，挿入損失と位相特性の直線性が共に比較的良好 であることがわかる。

図 6 は図 4 に示した構成での発振器発振スペクトル てある。4.4284 MHzで発振し，しかも高周波成分が $50 \mathrm{~dB}$ 以上抑圧されている。 3 種類の電気的境界条件 下での位相速度から，位相速度と $k^{2}$ を $f d$ 值の関数 の形で算出した結果が図 7 に示されている。図中には 実際のデバイスでの位相速度の測定結果 $2,657 \mathrm{~m} / \mathrm{s}$ が ○印で付加されている。

\section{5. 周波数変調特性}

図 4 の実験系において, 入力電圧と発振周波数静特 性の関係を測定した結果を図 8 に示している。入力と しての Gate電圧が, $-0.33 \mathrm{~V}<V_{\mathrm{G}-\mathrm{s}}<-0.17 \mathrm{~V}$ の範

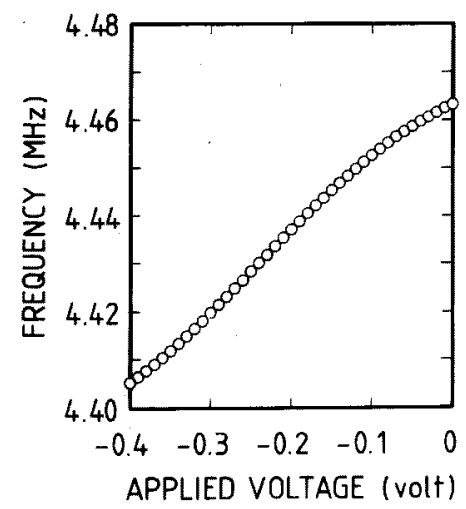

図 8 J-FET への印加電圧 $V_{\mathrm{G}-\mathrm{s}}$ と発振周波数の 関係の測定結果

Fig. 8. Measured relation between voltage $V_{\mathrm{G}-\mathrm{s}}$ applied to J-FET and oscillation frequency.

電学論A，112 巻 9 号, 平成 4 年
囲では電圧值と共に直線的に周波数が偏移するが, 特 に 4.415 4.442 MHz までの $27 \mathrm{kHz}$ の範囲は直線区

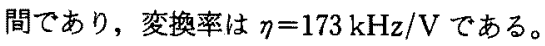

図 9 は J-FET への電圧印加に伴う電気的位相変化 に対応して発振周波数がどのように変化するかを示す もので,この関係が直線であることから, 図 9 におけ る印加電圧と発振周波数の関係の曲線部は移相器の特 性によるものであると考えられる。ここで, 図 8 の傾

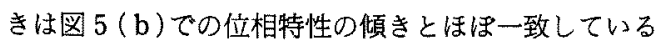

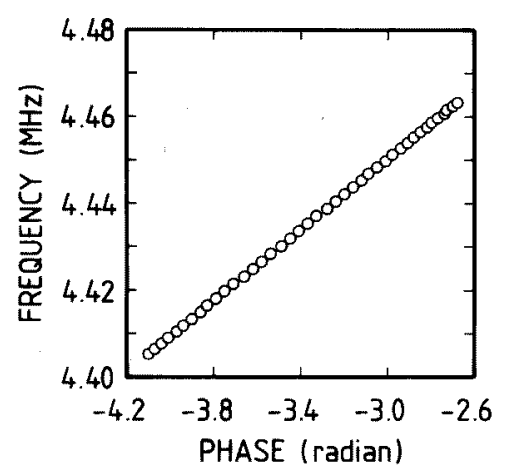

図 $9 \mathrm{~J}$-FET への印加電圧 $V_{\mathrm{G}-\mathrm{s}}$ に伴う電気的 位相変化と発振周波数の関係の測定結果

Fig. 9. Measured relation between electrical phase change, accompanied by voltage $V_{\mathrm{G}-\mathrm{s}}$ applied to $\mathrm{J}-\mathrm{FET}$, and oscillation frequency.

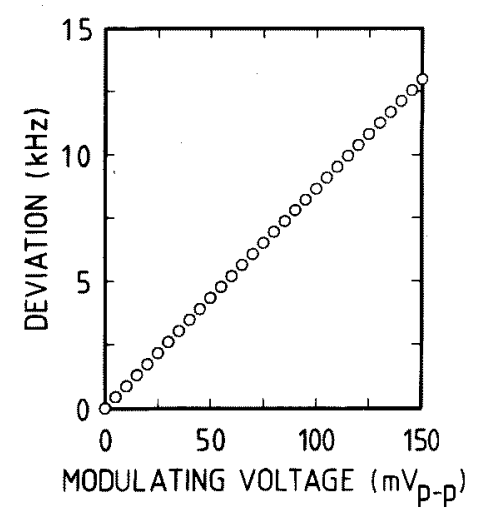

図 $10-0.25 \mathrm{~V}$ の直流バイアス下での変調 信号電圧 $V_{m}$ と周波数偏移 $\Delta f$ の関係 の測定結果

Fig. 10. Measured relation between modulating voltage $V_{m}$ and frequency deviation $\Delta f$ under $\mathrm{DC}$ bias voltage of $-0.25 \mathrm{~V}$. 


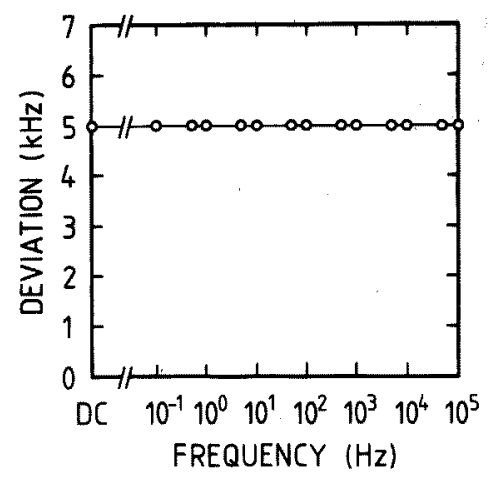

図 11 変調周波数 $f_{m}$ と周波数偏移 $\Delta f$ の 関係の湘定結果

Fig. 11. Measured relation between modulating frequency $f_{m}$ and frequency deviation $\Delta f$.

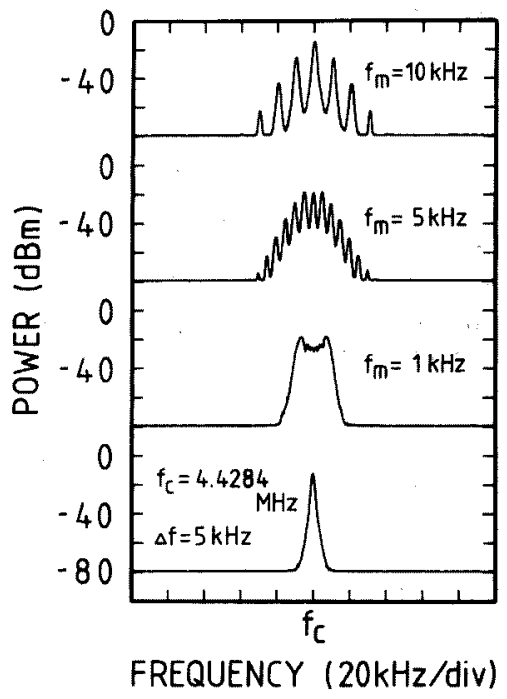

図 $12 f_{m}$ をパラメータとした FM 出力の スペクトル

Fig. 12. Spectrum of FM output signal as parameter of $f_{m}$.

ことがわかる。図 8 の直線区間に対応する $\mathrm{SH}$ 波の平 均速度分散は, $10 \mathrm{ppm} / \mathrm{kHz} \cdot \mathrm{mm}$ であり, 直線性へ の影響を無視し得る程度のものである。図10はJFET へのゲート電圧がー $0.25 \mathrm{~V}$ の直流バイアスと周 波数 $f_{m}$ が $1 \mathrm{kHz}$ の交流電圧を重盢した信号である場 合に, 変調信号の振幅と周波数偏移 $\Delta f$ の関係を測定 した結果で, 電圧振幅と $\Delta f$ の変換率 $\eta$ が $86.5 \mathrm{kHz}$ 的 $V_{\mathrm{p}-\mathrm{p}}(=173 \mathrm{kHz} / \mathrm{V})$ の直線関係が得られている。
変調信号電圧振幅を一定にした状態で周波数を DC から連続的に変化させることによって測定した変調周 波数と周波数偏移の関係が図 11 に示されている。直 流から $100 \mathrm{kHz}$ までの広範囲な周波数領域で平坦な 特性が得られた。この結果は, オーティオ帯を含むつ ナログ信号伝送に必要な条件を十分に満足するものて ある。図 12 は $f_{c}=4.4284 \mathrm{MHz}, \Delta f=5 \mathrm{kHz}$ のもと で観測された発振スペクトルの測定例を示したもの で, 変調周波数に等しい間隔で側波帯が現れているこ とがわかる。

\section{6.むすび}

本論文では，普通焼成によってジルコン酸鉛系圧電 セラミックス PZNT $(92 / 4.8)$ を作成し，材料定数を 求めると共に, 分極した圧電板上での SH 波の伝搬特 性を数值解析と実験の両面から検討している。SH 波 には多数のモードが存在するが，なかでも需次対称 モードは $f d$ 值が $1 \mathrm{MHz} \cdot \mathrm{mm}$ 以下の領域で, $k^{2}$ が $3 \%$ 以上の大きな值をとり，しかも速度分散性が数〜 $30 \mathrm{ppm} / \mathrm{kHz} \cdot \mathrm{mm}$ と低い值であることがわかった。

テーブキャスティング法で作成した基板に SH 波の 励振に有利なように横方向の分極を施した後で, 送受

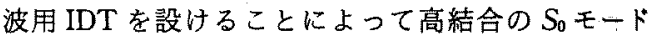
$\mathrm{SH}$ 波デバイスを作成した。このデバイスでは $A_{0}$ モ ードを含めて高次モードが存在しない, 実質的には単 一モードとして扱いうることが確認された。

$S_{0}$ モードを利用した SH 波遅延デパイスと増幅器 と移相器の組合せによって遅延線発振器を構成すると 共に, 移相器へ印加する電圧によって位相変化を誟起 し，これによって発振周波数が変化することを実駼的 に検討した。移相器の構成部品であるJ-FETの Gate-Source 間への印加電圧の変化と共に発振周波 数は直線的に変化した。電圧を印加しない場合の発振 スペクトルは高調波成分が $50 \mathrm{~dB}$ 以上抑圧され，単 一モード発振器としての良好な特性を示した。

振幅一定のもとでは DC から $100 \mathrm{kHz}$ までの広い 周波数範囲にわたって一定の周波数偏移が得られ， $S_{0}$ モード SH 波の速度分散が変調特性には実質的に影響 を及㴗さないことがわかった。この結果はPZNT (92/4.8) 基板が電位センサ用としても有効であること を物語っている。

(平成 3 年 11 月 8 日受付)

\section{文献}

(1) E. Sawaguchi: "Ferroelectricity versus antiferroelectricity in solid solutions of $\mathrm{PbZrO}_{3}$ and $\mathrm{PbTiO}_{3}{ }^{*}, J$. Phys. Soc. Japan, 8, 615 (1953)

(2) R. Clarke, A. M. Glazer, F. Ainger, D. Appleby, N. J. Poole 
\& S.G. Porter: "Phase transitions in lead zirconatetitanate and their applications in thermal detectors", Ferroelectrics, 11, 359 (1976)

(3) H. Matthews edited: Surface wave filters, Chap. 1 (1977) John Wiley \& Sons, New York

(4) K. Mizutani \& K. Toda: "Analysis of Lamb wave propagation characteristics in piezoelectric ceramic plates", Japan J. Appl. Phys., 24, Suppl. 24-1, 109 (1985)

(5) K. Mizutani \& K. Toda: "Propagation characteristics of SH-waves in piezoelectric ceramic plates", ibid., 25, Suppl. 25-1, 160 (1986)

（6）電子材料工業会編：表面波テバイスとその応用，応用編 (昭53) 日刊工業新聞社

(7) IRE Standards on Piezoelectric Crystals: Measurements of Piezoelectric Ceramics (1961)

（8）竹中：「圧電特性測定法」, 七ラミックス，24, 1176 (平元)

(9) G.W. Farnell \& E. Ackaya: "Field distributions for surface-skimming bulk-wave transducers", IEEE Trans. Sonics \& Ultrason., SU-26, 202 (1979)

(10) G. G. Koerber \& R. F. Vorgel: "SH-mode piezoelectric surface on rotated cuts", ibid., SU-20, 9 (1973)

(11) G. W. Farnell : "Symmetry considerations for elastic layer modes propagating in anisotropic piezoelectric crystals", ibid., SU-17, 229 (1970)

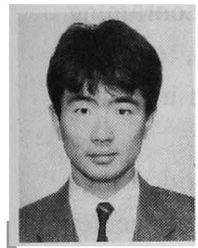

\section{杉 崎 五 郎 (非会員)}

昭和 42 年 2 月 2 日生。平成 3 年 3 月 東京理科大学大学院理工学研究科修士課 程電気工学専攻修了。現在, 同博士課程 在学中。ジルコン酸鉛系セラミックスの 圧電性に関する研究に従事。

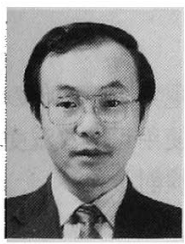

\section{竹 中 正 (正員)}

昭和 45 年芝浦工業大学電子工学科卒 業。 48 年電気通信大学大学院修士課程 通信材料工学専攻修了。同年 4 月東京理 科大学理工学部電気工学科助手, 講師
を経て, 平成 3 年 4 月同助教授, 現在に至る。工学博士。 61 年 8 月〜 62 年 8 月アメリカ・ペンシルパニア州立大学材 料科学研究所客員研究員。6 63 年 4 月より科学技術庁無機 材質研究所客員研究官。電子情報通信学会, 応用物理学 会, AIEEE, 米セラミック協会会員。

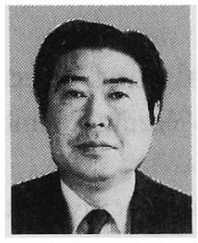

\section{坂 田 好一郎 (正員)}

昭和 6 年 2 月 22 日生。 28 年山形大学 工学部電気卒業。32 年東北大学大学院 修士課程修了。同年防衛大学電気助手。 36 年東北大学通研助手, 38 年同助教授。 44 年東京理科大学理工電気助教授, 46 年同教授。工学博 士。強誘電体を主体とした単結晶ならびに電子セラミック 材料の研究に従事。 49 年度オーム賞受賞。日本物理学会, 応用物理学会, 電子情報通信学会, 日本セラミック協会会 員。

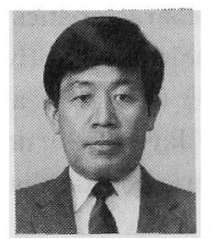

\section{戸田耕司（正員）}

昭和 15 年 11 月 12 日生。39 年 3 月防 衛大学校(電気工学専攻)卒業。4 4 年 3 月京都大学大学院工学研究科電気系修士 課程修了。同年 4 月防衛大学校電気工学 教室助手。 48 年 49 年スタンフォード大学電気工学科客 員助教授。現在, 防衛大学校電子工学科教授。工学博士。 表面波デバイス, 強誘電体材料, 音響撮像, センサなどの 研究に従事。 47 年度電子通信学会米沢賞, 60 年度科学技 術庁長官賞受賞。Sigma Xi 会員。アメリカ音響学会フェ ロー。 